Article

\title{
Novel Heat-Integrated Hybrid Distillation and Adsorption Process for Coproduction of Cellulosic Ethanol, Heat, and Electricity from Actual Lignocellulosic Fermentation Broth
}

\author{
Le Cao Nhien ${ }^{+}\left(\mathbb{D}\right.$, Nguyen Van Duc Long $^{\dagger}$ and Moonyong Lee * ${ }^{(\mathbb{D}}$ \\ School of Chemical Engineering, Yeungnam University, Gyeongsan 38541, Korea; nhienle@ynu.ac.kr (L.C.N.); \\ allenthelong@yu.ac.kr (N.V.D.L.) \\ * Correspondence: mynlee@yu.ac.kr; Tel.: +82-53-810-2512 \\ + These authors contributed equally to this work.
}

Citation: Nhien, L.C.; Van Duc Long, N.; Lee, M. Novel Heat-Integrated Hybrid Distillation and Adsorption Process for Coproduction of Cellulosic Ethanol, Heat, and Electricity from Actual Lignocellulosic Fermentation Broth. Energies 2021, 14, 3377. https:// doi.org/10.3390/en14123377

Academic Editor: Paolo Defilippis

Received: 30 April 2021

Accepted: 7 June 2021

Published: 8 June 2021

Publisher's Note: MDPI stays neutral with regard to jurisdictional claims in published maps and institutional affiliations.

Copyright: (C) 2021 by the authors. Licensee MDPI, Basel, Switzerland. This article is an open access article distributed under the terms and conditions of the Creative Commons Attribution (CC BY) license (https:// creativecommons.org/licenses/by/ $4.0 /)$.
Abstract: Cellulosic ethanol (CE) can not only be produced from a nonedible, cheap, and abundant lignocellulose feedstock but also can reduce carbon footprint significantly compared to starch ethanol. Despite great stimulation worldwide, CE production has not yet commercialized because of the complexity of lignocellulose. Therefore, intensive research and development are needed to improve CE technologies. In this study, a cost-efficient and sustainable design was proposed for the coproduction of CE, heat, and electricity from the actual lignocellulosic fermentation broth. First, a conventional coproduction process of CE, heat, and electricity based on hybrid distillation and adsorption (HDA) was simulated and optimized. Subsequently, various heat integrated (HI) techniques such as heat pump (HP), multi-effect distillation (MED), and combined HP-MED were evaluated to improve the CE process. The combined heat and power (CHP) process that utilized the combustible solids of the beer stillage was designed and integrated with the CE process. Structural alternatives were assessed for both economic and environmental impacts. The results show that the proposed HI-HDA process can save $36.9 \%$ and $33.6 \%$ of total annual costs and carbon footprint, respectively, compared to the conventional CE process. In the proposed HI-HDA coproduction process, the CE recovery process can be self-efficient in energy and the CHP can generate $12.0 \%$ more electricity than that in the conventional coproduction process.

Keywords: cellulosic ethanol; lignocellulosic biomass; hybrid distillation and absorption; process integration; coproduction

\section{Introduction}

The current fossil-based economy poses several crucial problems, such as mineralresource depletion and contribution to global warming. Thus, the transition to a renewable resource-based economy is essential for a sustainable future. Biomass, which is a carbonneutral material, is the most promising candidate to replace fossil fuels. Particularly, lignocellulosic biomass is the most abundant renewable material on Earth and is a readily renewable resource for the industry in forms of softwood, energy crops, grasses, and agricultural residues [1].

Biofuels, such as bioethanol, biodiesels, and biogas that are produced from lignocellulosic biomass in increasing demands have the potential to drive a sustainable bioeconomy. Of these, bioethanol is one of the most important biofuels that can be mixed with gasoline for use in current engines without the need for engine modification to reduce carbon monoxide and other smog-causing emissions. The first generation of bioethanol (i.e., starch bioethanol) is mainly produced by the fermentation of sugars in food crops, such as corn and wheat, and is already commercialized, being used in the transportation sector worldwide. Although the technologies related to starch bioethanol are well developed, the price of starch feedstock is relatively high and accounts for $40-70 \%$ of the total production cost [2]. 
Another drawback of starch bioethanol is the associated food-versus-fuel tradeoff, arising from the increased food prices and the detrimental effect on food supplies associated with its production and use. Therefore, the production of ellulosic ethanol (CE) from lignocellulosic biomass, a nonedible, cheap, and abundant material, has been extensively explored. Lignocellulosic feedstock, such as corn stover ethanol, can reduce carbon dioxide $\left(\mathrm{CO}_{2}\right)$ emissions by $37 \%$ and $86 \%$ more than corn ethanol and oil-based ethanol, respectively, resulting in the improved sustainability of bioethanol production [3,4].

However, the complex composition of lignocellulosic biomass, which consists of hemicellulose (20-35\%), cellulose (30-55\%), and lignin (10-25\%), results in the requirement for a high degree of complexity in the processing and separation technologies. This causes the production cost of CE to be considerably higher than that of starch bioethanol, even though lignocellulose is substantially cheaper than starch crops [5]. Therefore, commercialscale CE production is yet to begin, and further research and development activities are required. In recent years, several CE pilot and demonstration plants employing new costeffective technologies have been launched [6]. In 2015, Beta Renewables started producing $\mathrm{CE}$ at its 40 million gallons per year (MMgy) plant in Crescentino, Italy [7]. However, it was sold to pay off debts in 2018 because of the bankruptcy of its parent company [8]. Abengoa's 25 MMgy CE plant located in Kansas, USA, began operation in 2015; however, they were also declared bankrupt after only one year of operation [7]. In 2016, DuPont celebrated the opening of a 30 MMgy CE plant in Nevada, USA. By 2017, the plant was under new ownership by Verbio Vereinigte BioEnergie AG [7]. In spite of these efforts, it is clear that creating a more competitive global CE market is challenging.

CE production typically consists of three steps: pretreatment, fermentation, and separation. First, the biomass feedstock undergoes a pretreatment step prior to fermentation and production of the beer fermentation broth. This broth, which contains $3-12 \mathrm{wt} \%$ ethanol, is then separated to give ethanol in commercially acceptable purity. A large amount of water present in the fermentation broth and the formation of a homogeneous azeotropic ethanol/water mixture are two of the main reasons that the separation step is energy intensive. Various separation techniques have been proposed to overcome the challenges of an azeotropic mixture, such as azeotropic distillation (AD), adsorption, membrane vapor permeation, membrane pervaporation, extractive distillation (ED), and pressure swing distillation [9-12]. Of these, the capacities of pervaporation and vapor permeation have reached their limits and are cost intensive on an industrial scale [13]. ED is more energy effective than AD and is widely used in industrial bioethanol production [9]. A dividingwall column using extracting solvent ethylene glycol (EG) was reported to improve the energy requirement by $17 \%$ compared to the conventional process [14]. However, the use of EG as the extracting solvent may cause several serious environmental issues, so its use has been restricted in several countries [15]. Adsorption using molecular sieves has been reported to be an efficient way to overcome the ethanol/water azeotrope $[10,16]$. In particular, adsorption using molecular sieves is particularly popular for removing small amounts of water from an ethanol/water mixture because of its selectivity and ease of maintenance [12].

However, most studies on the ethanol separation process assume that the beer feed from the fermentation process is composed of only ethanol and water. This assumption results in a simpler process but does not represent the actual lignocellulosic composition. Breaking down the cellulose-hemicellulose-lignin structure can lead to the presence of more compounds in the fermentation output, resulting in the requirement for a more complex separation procedure $[17,18]$. Humbird et al. reported a cost-efficient process that converted lignocellulosic biomass to $\mathrm{CE}$, considering a real composition of corn stover [10]. The biomass feedstock was converted to CE through dilute-acid pretreatment, enzymatic hydrolysis, and saccharification processes. The dilute CE stream was then fed to two distillation columns and one adsorption column using molecular sieve to reach commercial-grade ethanol (99.5 wt \%). Based on the NREL (National Renewable Energy Laboratory) process, a coproduction process of ethanol and furfural was developed to 
efficiently utilize both the cellulose and hemicellulose parts in lignocellulose materials [16]. In these processes, lignin and unconverted cellulose and hemicellulose were used for the production of heat and electricity through the biomass combined heat and power (CHP) process. In the biomass $\mathrm{CHP}$ process, the direct $\mathrm{CO}_{2}$ emission can be close to zero because of the $\mathrm{CO}_{2}$ emissions from biomass combustion having already been absorbed during plant growth [19]. Utilizing the solid byproducts to reduce the solid waste disposal costs is currently the critical issue in industrial biorefinery [20,21]. In the study, obtaining a high degree of integration and utilizing all parts of lignocellulose are key strategies for reducing CE production costs to make it more competitive with fossil fuels.

In this study, a novel heat-integrated (HI) hybrid distillation and adsorption (HI-HDA) process for the coproduction of $\mathrm{CE}$, electricity, and heat from an actual lignocellulosic fermentation broth was proposed. First, a CE conventional process consisting of preconcentration distillation and HDA was simulated and optimized based on NREL processes [10]. Subsequently, various HI techniques such as heat pump (HP), multiple-effect distillation (MED), and combined HP-MED were applied to improve the energy efficiency of the CE separation process. The combustion, steam boiler, and turbine generation (or CHP process) were then proposed to utilize a lignin fraction in the beer stillage from CE purification process. For a fair comparison, structural alternatives were assessed for both economic and environmental impacts. Consequently, promising design and operating conditions for the coproduction of $\mathrm{CE}$, heat, and electricity were explored.

\section{Methods}

\subsection{Design and Simulation}

In this study, a process for the coproduction of $\mathrm{CE}$, heat, and electricity was designed with a CE production capacity of 120 kilotons per year (ktpy). Table 1 lists the component compositions of the actual fermentation broth in detail. The broth comprises a number of components, including $\mathrm{CE}$, water, gas $\left(\mathrm{CO}_{2}\right)$, soluble solids, and insoluble solids. A conventional process was designed based on processes reported previously $[10,16,22]$. Figure 1 shows a schematic flowsheet of the integrated process for coproduction of $\mathrm{CE}$, furfural, heat, and electricity from lignocellulosic feedstock. The process coproduces $C E$ and furfural, and the concept was initially proposed by Strømsnes et al. [16]. In a previous study, a novel reactive distillation with an extraction-distillation configuration was proposed to improve the furfural production process [22]. In the present study, a cost-effective design for the coproduction of $\mathrm{CE}$ and electricity from a lignocellulosic fermentation broth (Figure 1, inside the dashed line rectangle) was developed. The lignocellulosic feedstock first undergoes a pretreatment step of acidic hydrolysis using sulfuric acid as the catalyst. In this step, hemicellulose was converted into its sugar monomers: mainly xylose and glucose. The xylose solution was separated from the cellulose/lignin slurry by a solid/liquid separation unit and delivered to the furfural production process. The details of the furfural production process design are beyond the scope of this study. The cellulose/lignin slurry was then introduced to the enzymatic-hydrolysis and fermentation processes in which CE was produced. The fermentation broth, which contained 3-12 $\mathrm{wt} \% \mathrm{CE}$, was transferred into a distillation column to pre-concentrate $\mathrm{CE}$ to approximately $39 \mathrm{wt} \%$ as a vapor sidestream. This vapor stream was introduced to an HDA process to achieve a commercial purity of $99.5 \mathrm{wt} \%$. The beer stillage from the bottom of the pre-concentration column was transferred to a solid/liquid separator to separate the lignin and the water. Wastewater was sent to a wastewater treatment process to produce methane via anaerobic digestion. Methane and combustible solids were then burned to produce steam, which was used to supply the heating demand in the plant and generate electricity. 
Table 1. Feed mixture conditions and product specifications.

\begin{tabular}{|c|c|}
\hline Component & Mass Fraction (wt $\%$ ) \\
\hline $\mathrm{H}_{2} \mathrm{O}$ & $90.46 \%$ \\
\hline Extractives * & $0.21 \%$ \\
\hline Dextrose & $0.17 \%$ \\
\hline Xylose * & $0.04 \%$ \\
\hline Ash * & $0.90 \%$ \\
\hline Lactic acid & $0.05 \%$ \\
\hline Furfural & $0.01 \%$ \\
\hline Vanillin & $2.88 \%$ \\
\hline Ethanol & $3.16 \%$ \\
\hline $\mathrm{CO}_{2}$ & $0.11 \%$ \\
\hline Cellulose * & $0.61 \%$ \\
\hline Xylan * & $0.36 \%$ \\
\hline Ammonium sulphate * & $0.06 \%$ \\
\hline Diammonium phosphate * & $0.03 \%$ \\
\hline Protein * & $0.75 \%$ \\
\hline Cell mass * & $0.14 \%$ \\
\hline Ammonium acetate * & $0.03 \%$ \\
\hline Temperature $\left({ }^{\circ} \mathrm{C}\right)$ & 32 \\
\hline Pressure (atm) & 1 \\
\hline Mass flowrate $(\mathrm{kg} / \mathrm{h})$ & 455,247 \\
\hline CE purity $(w \mathrm{t} \%)$ & 99.5 \\
\hline
\end{tabular}
*insoluble solids.

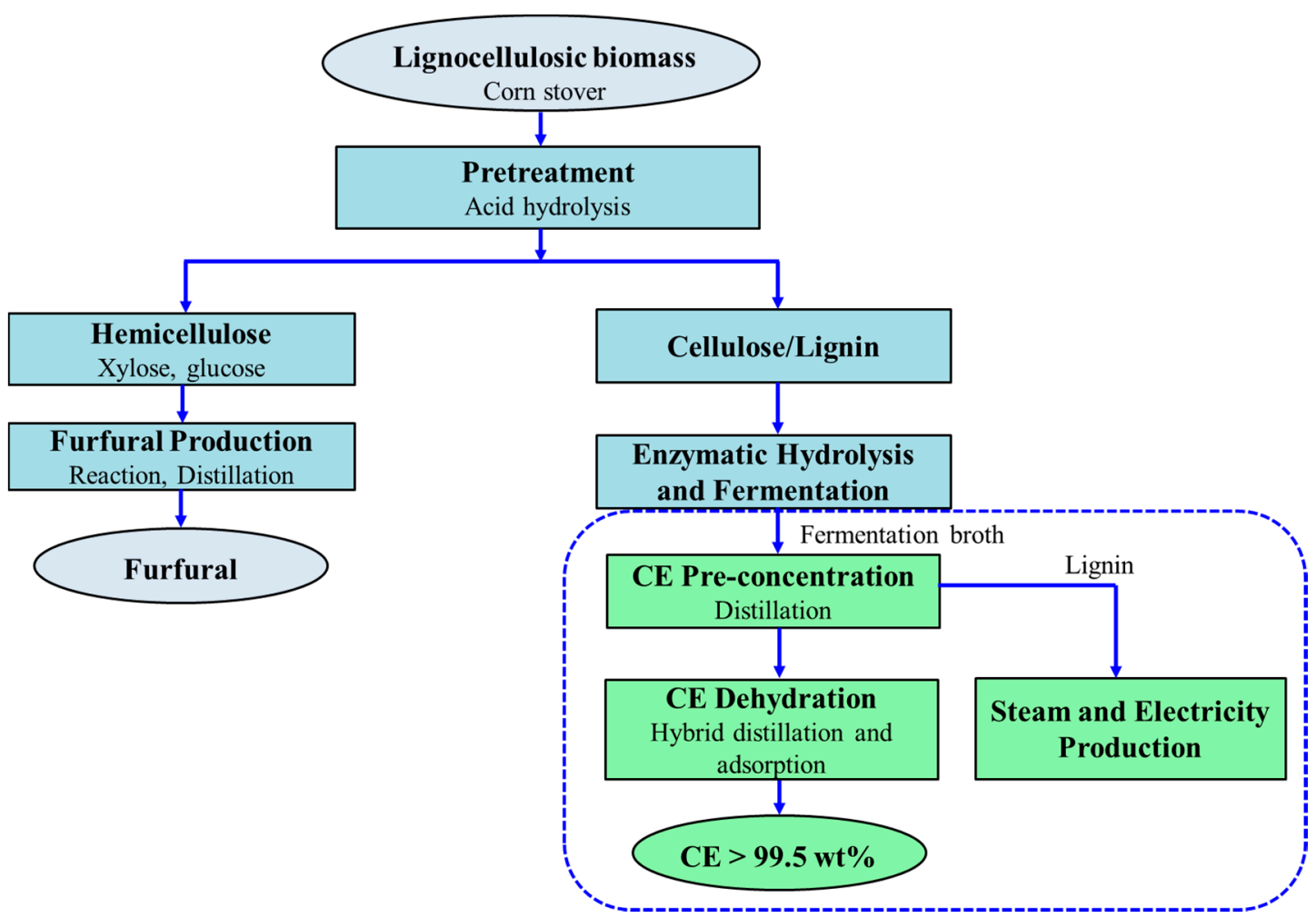

Figure 1. Schematic flowsheet of the process for coproduction of furfural, CE, heat, and electricity from lignocellulosic biomass.

All processes were rigorously simulated using Aspen HYSYS V.10. The physical properties for all components were taken from the Aspen database and the NREL report [10]. The non-random two-liquid (NRTL) fluid package was used to calculate the liquid activity 
coefficients. In addition, the UNIFAC method was used to estimate the missing binary parameters in the vapor-liquid equilibrium (VLE) data.

Several simulations were first run to optimize the distillation column and determine the initial structure. Subsequently, the feed location and total number of stages were adjusted to minimize the total annual cost (TAC) while maintaining the target product purity and recovery. The minimized TAC provided an optimal tradeoff between capital and operating costs; accordingly the optimal operating conditions and design were explored. The detailed optimization procedure for a distillation column was reported previously [23].

\subsection{Economic Evaluation}

For a fair comparison of the economic impact, the total investment cost (TIC), total operating cost (TOC), and TAC of all process alternatives were estimated, as described in previous studies [23]. Equipment costs were estimated using the correlations from Turton et al. and Biegler et al. [24,25]. The tray sizing function in Aspen HYSYS was used to estimate tray spacing, column heights, and the column diameters. A Chemical Engineering Index of 596.2 (corresponding to 2020) was used to update the TIC estimates. The heat exchangers, compressors, condensers, reboilers, tray stacks, column vessels, and blowers were considered in the TIC. A cooling water price of $0.35 \$ / G J$, low-pressure steam price of 13.28 \$/GJ, and high-pressure steam of 17.70 \$/GJ were used for the TOC calculations [25]. A plant lifetime of 10 years was assumed while a fixed interest rate of $8 \%$ was used for the TAC estimates.

\subsection{Environmental Assessment}

The total annual $\mathrm{CO}_{2}$ emissions (TCE) of all processes were calculated for environmental assessment. Gadalla's method was used to calculate the $\mathrm{CO}_{2}$ emissions for steam reboilers and compressors [26]:

$$
\left[\mathrm{CO}_{2}\right]_{\text {emiss }}=\left(\frac{Q_{\text {fuel }}}{N H V}\right)\left(\frac{C \%}{100}\right) \alpha,
$$

where $\mathrm{NHV}$ is the net heating value of the fuel, and $\mathrm{C} \%$ is the carbon content. The molar mass ratio of $\mathrm{CO}_{2}$ to $C$ was $\alpha=3.67$. Besides, $Q_{\text {fuel }}$, which denotes the amount of fuel used is calculated as below:

$$
Q_{\text {fuel }}=\left(\frac{Q_{\text {proc }}}{\lambda_{\text {proc }}}\right)\left(h_{\text {proc }}-419\right)\left(\frac{T_{F T B}-T_{0}}{T_{F T B}-T_{\text {stack }}}\right),
$$

where $Q_{\text {proc }}$ is the required heat duty of the system, $\lambda_{\text {proc }}(\mathrm{kJ} / \mathrm{kg})$ is the latent heat, and $h_{\text {proc }}$ $(\mathrm{kJ} / \mathrm{kg})$ is enthalpy of steam. The flame temperature $\left(T_{\text {FTB }}\right)$ is $1800{ }^{\circ} \mathrm{C}$, stack temperature $\left(T_{\text {stack }}\right)$ is $160^{\circ} \mathrm{C}$, and ambient temperature $\left(T_{0}\right)$ is and $25^{\circ} \mathrm{C}$.

\section{Results and Discussion}

In this study, the CE plant was designed with a capacity of 120 ktpy of CE based on processes reported previously $[10,16,22]$. A conventional process for the coproduction of $\mathrm{CE}$, heat, and electricity was designed and operating conditions were optimized. Several $\mathrm{HI}$ techniques, such as mechanical vapor recompression (MVR), MED, and combined MVR-MED, were applied to improve the CE recovery process. All the processes were evaluated for their economic and environmental impacts. The most promising design for the $\mathrm{CE}$ recovery process was found. The CHP process utilizing combustible solids in the beer stillage from the CE process was designed to supply heating and power demands of the plant. Finally, a cost-effective design with detailed design parameters and operating conditions was proposed for the coproduction of $\mathrm{CE}$, heat, and electricity from an actual lignocellulosic fermentation broth. 


\subsection{Conventional Coproduction Process of CE, Heat, and Electricity}

Figure 2 depicts the conventional process for the coproduction of $\mathrm{CE}$, heat, and electricity from the lignocellulosic fermentation broth. The feed is the output stream of the fermentation process, as shown in Figure 1 while Table 1 lists details of the feed composition and product specifications [16]. First, the fermentation broth was pressurized from $1 \mathrm{~atm}$ to $6 \mathrm{~atm}$ before being preheated from the bottom stream of $\mathrm{C} 1$. The preheated feed was introduced into distillation column $\mathrm{C} 1$ to separate the gas component $\left(\mathrm{CO}_{2}\right)$ as the top vapor stream and all insoluble solids and most of the water ( $94.6 \mathrm{wt} \%$ in the feed) as the bottom stream. The side vapor stream with $39.2 \mathrm{wt} \% \mathrm{CE}$, recovering $99.0 \mathrm{wt} \% \mathrm{CE}$ of the feed was withdrawn and delivered directly to the second distillation column C2. Most of the water was removed as the $\mathrm{C} 2$ bottom stream, while the $\mathrm{C} 2$ overhead vapor contained the ethanol/water. This system consists of two molecular-sieve columns packed with adsorbent beds. As the vapor flows through the column, water was selectively adsorbed in the beds while a $99.5 \mathrm{wt} \%$ CE stream flowed through. While one column absorbs water, the other is regenerating. By passing a slip stream of pure $\mathrm{CE}$ vapor back through the water-saturated bed under vacuum pressure, the bed was regenerated. The $72 \mathrm{wt} \% \mathrm{CE}$ stream, which was generated as ethanol was stripped of water, was cooled to $35^{\circ} \mathrm{C}$ to remove the remaining $\mathrm{CO}_{2}$. Subsequently, it was heated by the pure $\mathrm{CE}$ stream before being recycled back to $\mathrm{C} 2$. In the Aspen HYSYS environment, the adsorption columns were modeled as a component splitter, which was specified to achieve a product stream of $99.5 \mathrm{wt} \% \mathrm{CE}$ and a recycle stream of $72 \mathrm{wt} \% \mathrm{CE}$.

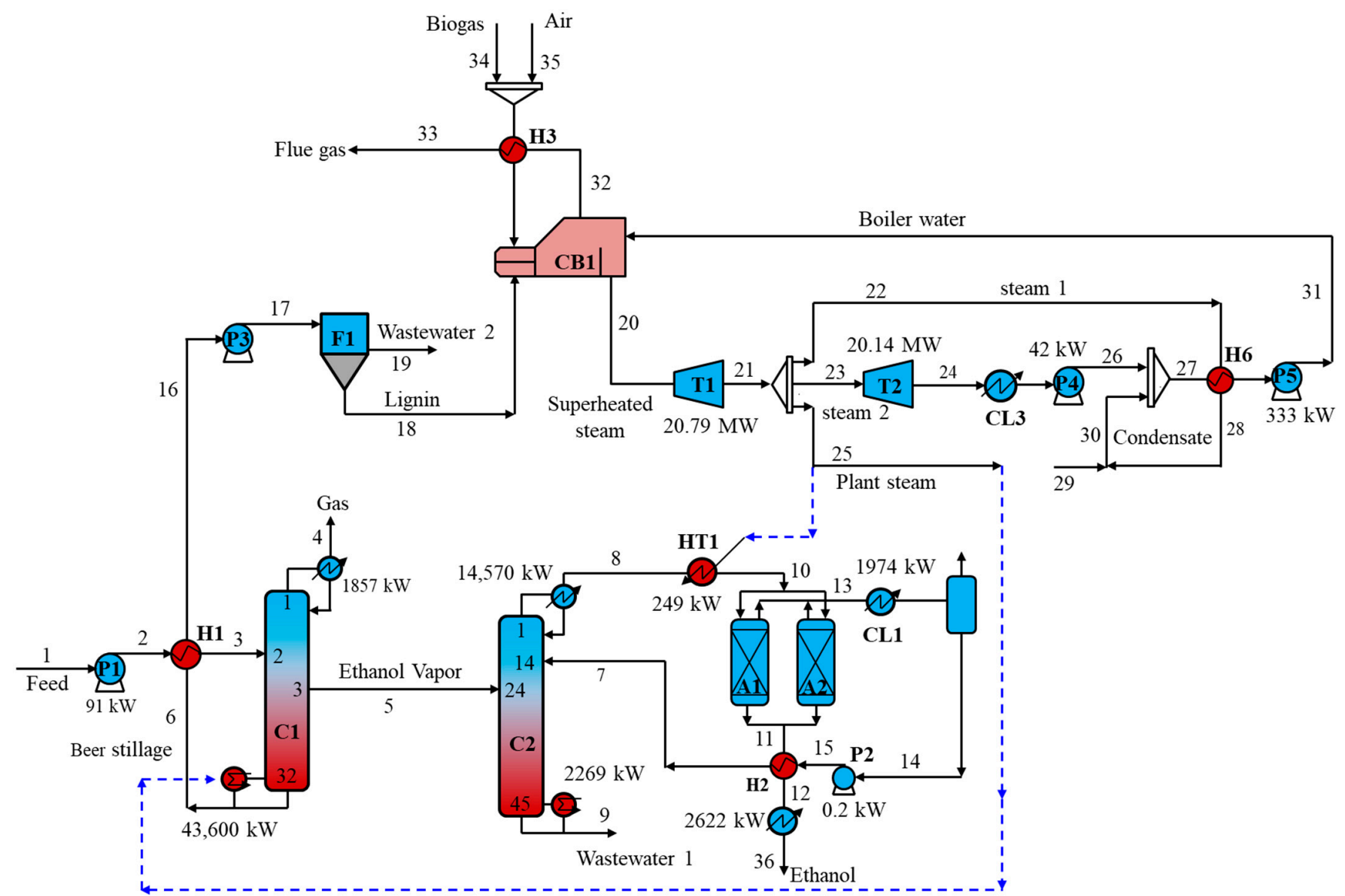

Figure 2. Schematic diagram of the conventional coproduction process of $\mathrm{CE}$, heat, and electricity from lignocellulosic fermentation broth. P1-5: Pumps; H1-6: heat exchangers; C1-2: distillation columns; A1-2: adsorption columns; HT1: heater; CL1-3: coolers; T1-2: turbines; CB1: combustor + boiler; F1: pressure filter. 
The $\mathrm{C} 1$ bottom stream comprised a residual solid material (lignin, xylan, and cellulose) in water. A forced circulation reboiler was proposed to accommodate solids at the bottom of the column [10]. The insoluble solids were less than $4 \mathrm{wt} \%$ and were assumed to be highly porous and so nominal liquid flow was assumed. The beer stillage was heat-exchanged with the beer feed to $43^{\circ} \mathrm{C}$, which is a suitable temperature for liquid/solid separation. This cooled stream was introduced into a pressure filter to produce a solid cake, which was subsequently dried with air to $40 \%$ moisture. The filter was simulated as a component splitter with a split factor of 1.0 and 0.05 , for solid and liquid components, respectively [10]. The wastewater was sent to the wastewater treatment process for anaerobic digestion, while the lignin cake was delivered to a burner. Although the wastewater treatment process was not simulated in this study, the amounts of methane and $\mathrm{CO}_{2}$ produced by anaerobic digestion of organic components in the wastewater were calculated and used as raw materials for combustion. The calculation is based on the combined chemical oxygen demand (COD) for the organic matter present in wastewater. The detailed calculation was included in Appendix A.

The biogas (methane $/ \mathrm{CO}_{2}$ ) was mixed with the air and preheated by the flue gas before being introduced into the burner. The burner was simulated as a conversion reactor in Aspen Plus, which assumes that all combustible material burns in oxygen with $100 \%$ conversion. The detailed reactions are as follows:

$$
\begin{gathered}
\text { Vanillin }+8.5 \text { Oxygen } \rightarrow 8 \mathrm{CO}_{2}+4 \mathrm{H}_{2} \mathrm{O} \\
\text { Cellulose }+6 \text { Oxygen } \rightarrow 6 \mathrm{CO}_{2}+5 \mathrm{H}_{2} \mathrm{O} \\
\text { Xylan }+5 \text { Oxygen } \rightarrow 5 \mathrm{CO}_{2}+\mathrm{H}_{2} \mathrm{O} \\
\text { Methane }+2 \text { Oxygen } \rightarrow \mathrm{CO}_{2}+2 \mathrm{H}_{2} \mathrm{O} \\
\text { Protein }+1.5 \text { Oxygen } \rightarrow \mathrm{CO}_{2}+0.8 \mathrm{H}_{2} \mathrm{O}+0.3 \mathrm{NO}_{2}+\mathrm{H}_{2} \mathrm{~S} \\
\text { Cell Mass + } 4 \text { Oxygen } \rightarrow \mathrm{CO}_{2}+0.9 \mathrm{H}_{2} \mathrm{O}+2 \mathrm{NO}_{2}
\end{gathered}
$$

On the other hand, water fed to the heat exchanger circuit in the combustor was boiled and superheated to a high-pressure (HP) steam $\left(435^{\circ} \mathrm{C}, 50 \mathrm{~atm}\right)$. This HP steam was used to drive the primary turbine (T1), which turns a generator produced electricity for the plant. The isentropic efficiency of T1 were designed at $85 \%$. The low-pressure (LP) steam $\left(235{ }^{\circ} \mathrm{C}, 9.5 \mathrm{~atm}\right)$ from turbine $\mathrm{T} 1$ was then split into three steams for different uses in the process. Furthermore, $35 \mathrm{wt} \%$ of the LP steam was used to supply heating demand of $\mathrm{C} 1, \mathrm{C} 2$ reboilers and heater HT1 in the CE recovery process. For maximizing energy conversion, $56 \mathrm{wt} \%$ of the LP steam was used to drive the turbine $\mathrm{T} 2$ as steam was taken down to a vacuum pressure of $0.1 \mathrm{~atm}$. The steam turbine $\mathrm{T} 2$ also produced electricity with the isentropic efficiency of $85 \%$. The T2 output stream was condensed with cooling water and pressurized to $9.5 \mathrm{~atm}$. In addition, $11 \mathrm{wt} \%$ of the LP steam was used to preheat the boiler feed water before being mixed with the condensate from the T2 output. The split ratio was adjusted to equal the heating demand of the plant, whereas excess electricity can be sold back to the grid. Furthermore, 20.79 MW and 20.14 MW of electricity were generated from the T1, T2, respectively, which corresponds to a cycle energy efficiency of $21.9 \%$. All stream information including temperature, pressure, vapor fraction, and component composition is listed in Table 2. 
Table 2. Stream table of the conventional coproduction process of CE, heat, and electricity from lignocellulosic fermentation broth.

\begin{tabular}{|c|c|c|c|c|c|c|c|c|c|c|c|c|c|}
\hline Stream & 1 & 2 & 3 & 4 & 5 & 6 & 7 & 8 & 9 & 10 & 11 & 12 & 13 \\
\hline Vapor fraction & 0.0 & 0.0 & 0.0 & 1.0 & 1.0 & 0.0 & 0.3 & 1.0 & 0.0 & 1.0 & 1.0 & 0.8 & 1.0 \\
\hline Temperature $\left({ }^{\circ} \mathrm{C}\right)$ & 32 & 32 & 108 & 55 & 115 & 126 & 106 & 89 & 119 & 116 & 116 & 89 & 116 \\
\hline Pressure (atm) & 1.0 & 6.0 & 6.0 & 2.0 & 2.0 & 2.3 & 2.5 & 1.5 & 1.9 & 1.5 & 1.5 & 1.5 & 1.5 \\
\hline \multicolumn{14}{|l|}{ Mass fraction } \\
\hline Water & 0.905 & 0.905 & 0.905 & 0.025 & 0.608 & 0.932 & 0.278 & 0.074 & 0.999 & 0.074 & 0.005 & 0.005 & 0.278 \\
\hline Extractives * & 0.002 & 0.002 & 0.002 & 0.000 & 0.000 & 0.002 & 0.000 & 0.000 & 0.000 & 0.000 & 0.000 & 0.000 & 0.000 \\
\hline Dextrose & 0.002 & 0.002 & 0.002 & 0.000 & 0.000 & 0.002 & 0.000 & 0.000 & 0.000 & 0.000 & 0.000 & 0.000 & 0.000 \\
\hline Lactic acid & 0.001 & 0.001 & 0.001 & 0.000 & 0.000 & 0.001 & 0.000 & 0.000 & 0.000 & 0.000 & 0.000 & 0.000 & 0.000 \\
\hline Vanillin & 0.029 & 0.029 & 0.029 & 0.000 & 0.000 & 0.031 & 0.000 & 0.000 & 0.000 & 0.000 & 0.000 & 0.000 & 0.000 \\
\hline Ethanol & 0.032 & 0.032 & 0.032 & 0.130 & 0.392 & 0.000 & 0.720 & 0.925 & 0.001 & 0.925 & 0.995 & 0.995 & 0.720 \\
\hline $\mathrm{CO}_{2}$ & 0.001 & 0.001 & 0.001 & 0.845 & 0.000 & 0.000 & 0.002 & 0.001 & 0.000 & 0.001 & 0.000 & 0.000 & 0.002 \\
\hline Cellulose & 0.006 & 0.006 & 0.006 & 0.000 & 0.000 & 0.007 & 0.000 & 0.000 & 0.000 & 0.000 & 0.000 & 0.000 & 0.000 \\
\hline Xylan * & 0.004 & 0.004 & 0.004 & 0.000 & 0.000 & 0.004 & 0.000 & 0.000 & 0.000 & 0.000 & 0.000 & 0.000 & 0.000 \\
\hline Ammonium sulphate* & 0.001 & 0.001 & 0.001 & 0.000 & 0.000 & 0.001 & 0.000 & 0.000 & 0.000 & 0.000 & 0.000 & 0.000 & 0.000 \\
\hline Protein * & 0.008 & 0.008 & 0.008 & 0.000 & 0.000 & 0.008 & 0.000 & 0.000 & 0.000 & 0.000 & 0.000 & 0.000 & 0.000 \\
\hline Cell Mass * & 0.001 & 0.001 & 0.001 & 0.000 & 0.000 & 0.002 & 0.000 & 0.000 & 0.000 & 0.000 & 0.000 & 0.000 & 0.000 \\
\hline Nitrogen & 0.000 & 0.000 & 0.000 & 0.000 & 0.000 & 0.000 & 0.000 & 0.000 & 0.000 & 0.000 & 0.000 & 0.000 & 0.000 \\
\hline Methane & 0.000 & 0.000 & 0.000 & 0.000 & 0.000 & 0.000 & 0.000 & 0.000 & 0.000 & 0.000 & 0.000 & 0.000 & 0.000 \\
\hline Stream & 14 & 15 & 16 & 17 & 18 & 19 & 20 & 21 & 22 & 23 & 24 & 25 & 26 \\
\hline Vapor fraction & 0.0 & 0.0 & 0.0 & 0.0 & 0.0 & 0.0 & 1.0 & 1.0 & 1.0 & 1.0 & 0.9 & 1.0 & 0.0 \\
\hline Temperature $\left({ }^{\circ} \mathrm{C}\right)$ & 35 & 35 & 43 & 43 & 43 & 43 & 435 & 236 & 236 & 236 & 46 & 236 & 46 \\
\hline Pressure (atm) & 1.5 & 2.5 & 1.3 & 6.3 & 6.3 & 6.3 & 50.0 & 9.5 & 9.5 & 9.5 & 0.1 & 9.5 & 9.5 \\
\hline Mass flowrate $(\mathrm{kg} / \mathrm{h})$ & 4894 & 4894 & 418,254 & 418,254 & 44,870 & 373,385 & 206,034 & 206,034 & 18,556 & 115,558 & 115,558 & 71,920 & 115,558 \\
\hline \multicolumn{14}{|l|}{ Mass fraction } \\
\hline Water & 0.278 & 0.278 & 0.932 & 0.932 & 0.434 & 0.991 & 1.000 & 1.000 & 1.000 & 1.000 & 1.000 & 1.000 & 1.000 \\
\hline Extractives * & 0.000 & 0.000 & 0.002 & 0.002 & 0.001 & 0.002 & 0.000 & 0.000 & 0.000 & 0.000 & 0.000 & 0.000 & 0.000 \\
\hline Dextrose & 0.000 & 0.000 & 0.002 & 0.002 & 0.001 & 0.002 & 0.000 & 0.000 & 0.000 & 0.000 & 0.000 & 0.000 & 0.000 \\
\hline Ash * & 0.000 & 0.000 & 0.010 & 0.010 & 0.090 & 0.000 & 0.000 & 0.000 & 0.000 & 0.000 & 0.000 & 0.000 & 0.000 \\
\hline Lactic acid & 0.000 & 0.000 & 0.001 & 0.001 & 0.000 & 0.001 & 0.000 & 0.000 & 0.000 & 0.000 & 0.000 & 0.000 & 0.000 \\
\hline Vanillin & 0.000 & 0.000 & 0.031 & 0.031 & 0.287 & 0.001 & 0.000 & 0.000 & 0.000 & 0.000 & 0.000 & 0.000 & 0.000 \\
\hline Ethanol & 0.720 & 0.720 & 0.000 & 0.000 & 0.000 & 0.000 & 0.000 & 0.000 & 0.000 & 0.000 & 0.000 & 0.000 & 0.000 \\
\hline
\end{tabular}


Table 2. Cont.

\begin{tabular}{|c|c|c|c|c|c|c|c|c|c|c|c|c|c|}
\hline Stream & 1 & 2 & 3 & 4 & 5 & 6 & 7 & 8 & 9 & 10 & 11 & 12 & 13 \\
\hline $\mathrm{CO}_{2}$ & 0.002 & 0.002 & 0.000 & 0.000 & 0.000 & 0.000 & 0.000 & 0.000 & 0.000 & 0.000 & 0.000 & 0.000 & 0.000 \\
\hline Cellulose & 0.000 & 0.000 & 0.007 & 0.007 & 0.061 & 0.000 & 0.000 & 0.000 & 0.000 & 0.000 & 0.000 & 0.000 & 0.000 \\
\hline Xylan * & 0.000 & 0.000 & 0.004 & 0.004 & 0.036 & 0.000 & 0.000 & 0.000 & 0.000 & 0.000 & 0.000 & 0.000 & 0.000 \\
\hline Protein ${ }^{*}$ & 0.000 & 0.000 & 0.008 & 0.008 & 0.075 & 0.000 & 0.000 & 0.000 & 0.000 & 0.000 & 0.000 & 0.000 & 0.000 \\
\hline Cell Mass * & 0.000 & 0.000 & 0.002 & 0.002 & 0.014 & 0.000 & 0.000 & 0.000 & 0.000 & 0.000 & 0.000 & 0.000 & 0.000 \\
\hline Oxygen & 0.000 & 0.000 & 0.000 & 0.000 & 0.000 & 0.000 & 0.000 & 0.000 & 0.000 & 0.000 & 0.000 & 0.000 & 0.000 \\
\hline Nitrogen & 0.000 & 0.000 & 0.000 & 0.000 & 0.000 & 0.000 & 0.000 & 0.000 & 0.000 & 0.000 & 0.000 & 0.000 & 0.000 \\
\hline Stream & 27 & 28 & 29 & 30 & 31 & 32 & 33 & 34 & 35 & 36 & & & \\
\hline Vapor fraction & 0.0 & 0.0 & 0.0 & 0.0 & 0.0 & 0.0 & 1.0 & 1.0 & 1.0 & 0.0 & & & \\
\hline Temperature $\left({ }^{\circ} \mathrm{C}\right)$ & 82 & 138 & 125 & 128 & 132 & 289 & 175 & 35 & 25 & 89 & & & \\
\hline Pressure (atm) & 9.5 & 9.5 & 9.5 & 9.5 & 50.0 & 1.0 & 1.0 & 1.0 & 1.0 & 1.5 & & & \\
\hline Mass flowrate (kg/h) & 206,034 & 18,556 & 71,920 & 90,476 & 206,034 & 340,687 & 340,687 & 15,649 & 280,170 & 14,317 & & & \\
\hline \multicolumn{14}{|l|}{ Mass fraction } \\
\hline Water & 1.000 & 1.000 & 1.000 & 1.000 & 1.000 & 1.000 & 1.000 & 0.000 & 0.000 & 0.005 & & & \\
\hline Extractives * & 0.000 & 0.000 & 0.000 & 0.000 & 0.000 & 0.000 & 0.000 & 0.000 & 0.000 & 0.000 & & & \\
\hline Dextrose & 0.000 & 0.000 & 0.000 & 0.000 & 0.000 & 0.000 & 0.000 & 0.000 & 0.000 & 0.000 & & & \\
\hline Lactic acid & 0.000 & 0.000 & 0.000 & 0.000 & 0.000 & 0.000 & 0.000 & 0.000 & 0.000 & 0.000 & & & \\
\hline Vanillin & 0.000 & 0.000 & 0.000 & 0.000 & 0.000 & 0.000 & 0.000 & 0.000 & 0.000 & 0.000 & & & \\
\hline Ethanol & 0.000 & 0.000 & 0.000 & 0.000 & 0.000 & 0.000 & 0.000 & 0.000 & 0.000 & 0.995 & & & \\
\hline Ammonia & 0.000 & 0.000 & 0.000 & 0.000 & 0.000 & 0.000 & 0.000 & 0.000 & 0.000 & 0.000 & & & \\
\hline $\mathrm{CO}_{2}$ & 0.000 & 0.000 & 0.000 & 0.000 & 0.000 & 0.000 & 0.000 & 0.741 & 0.000 & 0.000 & & & \\
\hline Cellulose & 0.000 & 0.000 & 0.000 & 0.000 & 0.000 & 0.000 & 0.000 & 0.000 & 0.000 & 0.000 & & & \\
\hline Xylan * & 0.000 & 0.000 & 0.000 & 0.000 & 0.000 & 0.000 & 0.000 & 0.000 & 0.000 & 0.000 & & & \\
\hline Ammonium sulphate * & 0.000 & 0.000 & 0.000 & 0.000 & 0.000 & 0.000 & 0.000 & 0.000 & 0.000 & 0.000 & & & \\
\hline Protein ${ }^{*}$ & 0.000 & 0.000 & 0.000 & 0.000 & 0.000 & 0.000 & 0.000 & 0.000 & 0.000 & 0.000 & & & \\
\hline Cell mass * & 0.000 & 0.000 & 0.000 & 0.000 & 0.000 & 0.000 & 0.000 & 0.000 & 0.000 & 0.000 & & & \\
\hline Oxygen & 0.000 & 0.000 & 0.000 & 0.000 & 0.000 & 0.000 & 0.000 & 0.000 & 0.233 & 0.000 & & & \\
\hline Nitrogen & 0.000 & 0.000 & 0.000 & 0.000 & 0.000 & 0.000 & 0.000 & 0.000 & 0.767 & 0.000 & & & \\
\hline Methane & 0.000 & 0.000 & 0.000 & 0.000 & 0.000 & 0.000 & 0.000 & 0.259 & 0.000 & 0.000 & & & \\
\hline
\end{tabular}

* insoluble solids. 
Figure 1 shows the key design parameters of the optimized conventional coproduction process. Table 3 lists the key design parameters and hydraulics of all distillation columns used in the conventional process. The results show that $\mathrm{C} 1$ requires energy of 43,600 kW and $18,570 \mathrm{~kW}$ in the reboiler and condenser, respectively, whereas C2 requires $2269 \mathrm{~kW}$ and $14,570 \mathrm{~kW}$ in the reboiler and condenser, respectively. The high CE recovery of $99 \mathrm{wt} \%$ results in the relatively high energy usage in the $\mathrm{C} 1$ reboiler, which accounts for the tradeoff between CE loss and energy requirements. LP steam was used for all reboilers in the conventional process.

Table 3. Design parameters of all distillation columns.

\begin{tabular}{ccc}
\hline & C1 & C2 \\
\hline Tray type & Valve (Ballast-V1) & Valve (Ballast-V1) \\
Column diameter (m) & 3.4 & 2.8 \\
Number of trays & 32 & 45 \\
Number of flow paths & 1 & 1 \\
Max flooding (\%) & 85.5 & 85.0 \\
Tray spacing (m) & 0.61 & 0.61 \\
\hline
\end{tabular}

\subsection{Improvement of the Coproduction Process of CE, Heat, and Electricity}

Applying an appropriate heat-integrated technique is crucial for maximizing heat recovery in any chemical/biochemical process. Although distillation is the most common separation technology in chemical/biochemical processes, it has a relatively low thermodynamic efficiency. A distillation column often consumes a large amount of energy at high temperatures in the reboiler, whereas a similar amount of energy is released at low temperatures in the condenser [27]. As shown in Figure 1, heat is rejected at the C1 condenser, $\mathrm{C} 2$ condenser, and cooler CL1, whereas a large amount of energy is required in the C1 reboiler, C2 reboiler, and heater HT1. Therefore, there was an opportunity to make an energy integration to utilize the heat sources (condensers) to supply the heat sink (reboilers), resulting in a decrease in the energy requirement of the entire process.

\subsubsection{HP-Integrated HDA of the CE Process}

HP are state-of-the-art systems that can improve the energy efficiency of conventional distillation by transfer heat from a lower temperature at a condenser to a higher temperature at a reboiler. Several HP concepts such as MVR, vapor compression, and thermal vapor recompression have been proposed to upgrade the discharge energy in the condenser to reduce the consumed valuable utilities [27]. Of these, MVR, which is an energy-efficient system for binary distillation, has been widely applied in industrial separation processes [27]. Figure 3 shows a schematic diagram of the MVR configuration of the CE process with the main design parameters. First, the top vapor from C2, which was used as the heat transfer medium to supply heat to the $\mathrm{C} 1$ reboiler, was pressurized from $1.5 \mathrm{~atm}$ to $6.7 \mathrm{~atm}$ at $180{ }^{\circ} \mathrm{C}$ by compressor $\mathrm{CP} 1$. The pressure ratio of $\mathrm{CP} 1$ was designed to obtain a minimum temperature difference of $10{ }^{\circ} \mathrm{C}$ in heat exchanger $\mathrm{H} 3$. The stream from $\mathrm{C} 1$ going to the reboiler was heated by the compressor output through heat exchanger $\mathrm{H} 3$ and fed to the $\mathrm{C} 1$ reboiler to obtain the target temperature. The $\mathrm{C} 1$ reboiler produced two outlet streams: the vapor stream was recycled back to $C 1$, and the liquid stream was used to preheat the beer feed before going to the lignin combustion part. After transferring heat to the $\mathrm{H} 3$ cold inlet, the hot outlet of $\mathrm{H} 3\left(170^{\circ} \mathrm{C}\right)$ was depressurized and fed to the $\mathrm{C} 2$ condenser to be partially condensed at $89{ }^{\circ} \mathrm{C}$. The liquid output of the $\mathrm{C} 2$ condenser was refluxed to $\mathrm{C} 2$, whereas the vapor from the $\mathrm{C} 2$ condenser was heated further to $116{ }^{\circ} \mathrm{C}$ before being introduced into the adsorption column. The results show that the HP-assisted HDA process can save up to $72.4 \%$ and $36.5 \%$ of energy requirements in the condensers and reboilers, respectively, compared to the conventional CE production process. However, a multistage compressor (pressure ratio of 4.5) was required to pressurize the top vapor from $1.5 \mathrm{~atm}$ at $89^{\circ} \mathrm{C}$ to $6.7 \mathrm{~atm}$ at $180^{\circ} \mathrm{C}$ for safe compressor operation. The disadvantages 
of using an HP process are the high investment costs and the process complexity associated with using a multistage compressor. Considering the sustainability of the process, the lower efficiency of the electricity source compared to the heat source results in higher $\mathrm{CO}_{2}$ emissions in a compressor than in a reboiler with the same power [28]. The results show that the HP process can reduce the energy requirements of reboilers and condensers by $36.5 \%$ and $72.4 \%$, respectively, compared to the conventional CE production process. However, the TIC of the HP process is $70.7 \%$ higher than that of the CE base case. Overall, the HP-integrated HAD process can save $28.9 \%$ and $21.0 \%$ of the TAC and TCE, respectively, compared to the conventional CE production process.

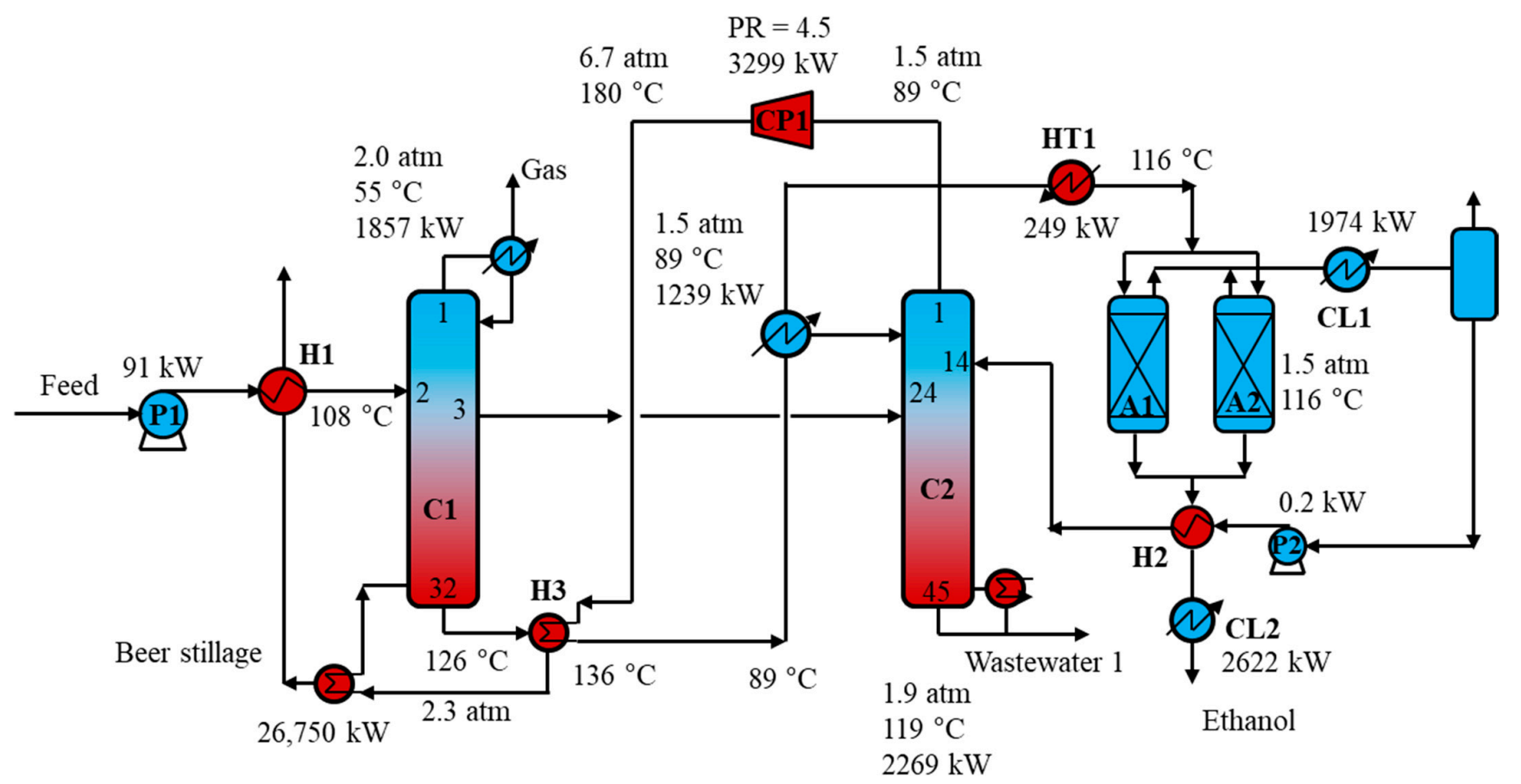

Figure 3. Schematic diagram of HP-integrated HDA for the CE production process from lignocellulosic fermentation broth. P1-2: pump; H1-2: heat exchangers; CP1: compressor; CL1-2: coolers; HT1: heaters; C1-2: distillation columns; A1-2: adsorption columns.

\subsubsection{MED-Integrated HDA of the CE Process}

MED consisting of two distillation columns, one operating at high pressure and the other operating at low pressure, is derived from a particular variant of heat integration. In this arrangement, a condenser of a high-pressure column acts as a reboiler of a lowpressure column [27]. Consequently, MED can utilize the rejected heat in the condenser of the high-pressure column to supply heat to the reboiler of the low-pressure column without using a compressor. Figure 4 depicts the schematic diagram of the MED-integrated HDA for the CE production process investigated in this study with key design parameters included. Compared to the conventional process, the first distillation column had a lower pressure of $1.3 \mathrm{~atm}$, whereas the second column had a higher pressure of $4.5 \mathrm{~atm}$. The operating pressures of the two columns were designed to obtain a temperature difference of $10^{\circ} \mathrm{C}$ between the $\mathrm{C} 2$ top vapor and $\mathrm{C} 1$ bottom stream. In particular, the $\mathrm{C} 1$ bottom stream received heat from the $\mathrm{C} 1$ top vapor through heat exchanger $\mathrm{H} 3$ before being introduced to the $\mathrm{C} 1$ reboiler. Upon boiling of the stream in the reboiler, two new streams were produced. Of these, the vapor stream was recycled back to $\mathrm{C} 1$, and the liquid stream was used to preheat the beer feed before being sent to the CHP process. On the other hand, after transferring heat to the $\mathrm{C} 1$ bottom stream, the $\mathrm{C} 2$ top vapor stream was split into two streams: a liquid stream which was recycled to $\mathrm{C} 2$ in the first stage and a remaining vapor stream which was depressurized and input into the adsorption system. However, 
because $\mathrm{C} 1$ had a lower pressure than $\mathrm{C} 2$, a compressor was required to pressurize the side vapor stream of $\mathrm{C} 1$ before it was fed into $\mathrm{C} 2$. The $\mathrm{C} 1$ side vapor stream was pressurized from $1.0 \mathrm{~atm}$ to $4.4 \mathrm{~atm}$ before being introduced to the $\mathrm{C} 2$. The compressor CP2 has a relatively high power of $2904 \mathrm{~kW}$ and a pressure ratio of 4.4, which requires a multistage compressor instead of a one-stage compressor. The cost of investment in such a system is high and it introduces significant complexity in operation. Furthermore, the discharge temperature of $247^{\circ} \mathrm{C}$ can cause compressor overheating and corrosion problems, which are currently serious issues of using the compressor in industry [29]. The results show that the MED-integrated HDA process can save up to $80.4 \%$ and $38.9 \%$ of energy requirements in the condensers and reboilers, respectively, compared to the conventional CE production process. Although the TIC of the MED process was $66.9 \%$ higher than that of the CE base case, the MED-integrated HDA process can save $31.4 \%$ and $25.2 \%$ of the TAC and TCE, respectively, compared to the conventional $\mathrm{CE}$ production process.

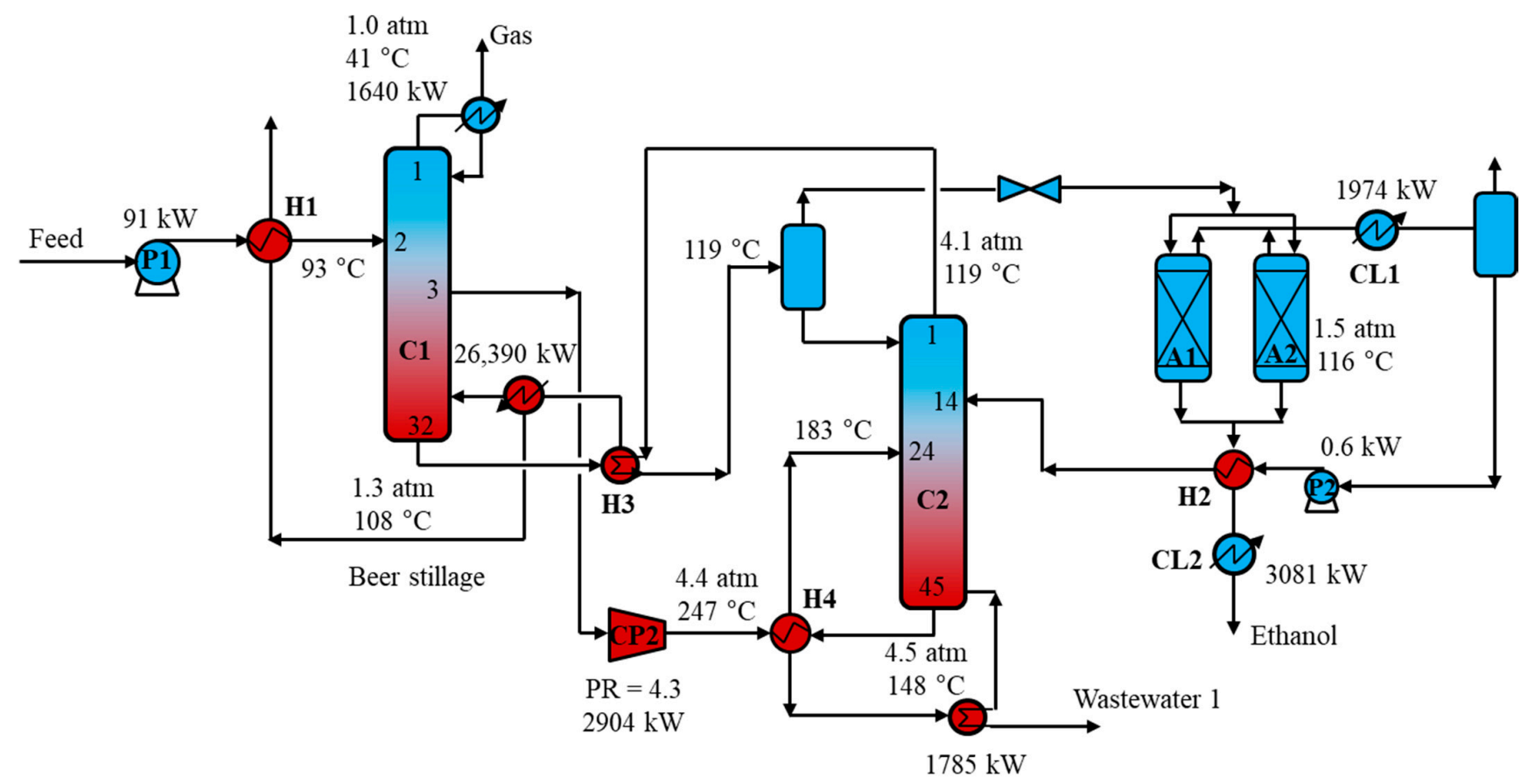

Figure 4. Schematic diagram of MED-integrated HAD for the CE production process from lignocellulosic fermentation broth. P1-2: pump; H1-4: heat exchangers; CP2: compressor; CL1-2: coolers; C1-2: distillation columns; A1-2: adsorption columns.

\subsubsection{HI-HAD of the CE Process}

Although the HP and MED processes described above show great performance in terms of energy efficiency, the use of multistage compressors is rather unstable and requires complex operation. Therefore, a heat-integrated HDA (HI-HDA) process that combines HP and MED was investigated. Figure 5 shows a schematic diagram of the HI-HDA process for $\mathrm{CE}$ production with key design parameters included. Compared to the conventional process, the $\mathrm{C} 1$ distillation column had a lower pressure, whereas the $\mathrm{C} 2$ pressure was kept constant. A heat pump with a compressor was integrated to utilize the heat source in the $\mathrm{C} 2$ condenser to supply heat to the $\mathrm{C} 1$ reboiler. Lowering the $\mathrm{C} 1$ pressure resulted in the need for a low-pressure ratio of compressor CP3. In particular, the $\mathrm{C} 2$ top vapor was pressurized from $1.5 \mathrm{~atm}$ at $89^{\circ} \mathrm{C}$ to $3.9 \mathrm{~atm}$ at $147^{\circ} \mathrm{C}$, such that a one-stage compressor with a pressure ratio of 2.6 was sufficient. The $\mathrm{C} 1$ bottom stream was heated by the CP3 outlet and fed into the $\mathrm{C} 1$ reboiler. The $\mathrm{C} 1$ reboiler produced two streams: a vapor stream which was recycled back to $\mathrm{C} 1$ and a liquid stream which was used to preheat the beer feed before being introduced to the combustion part. 


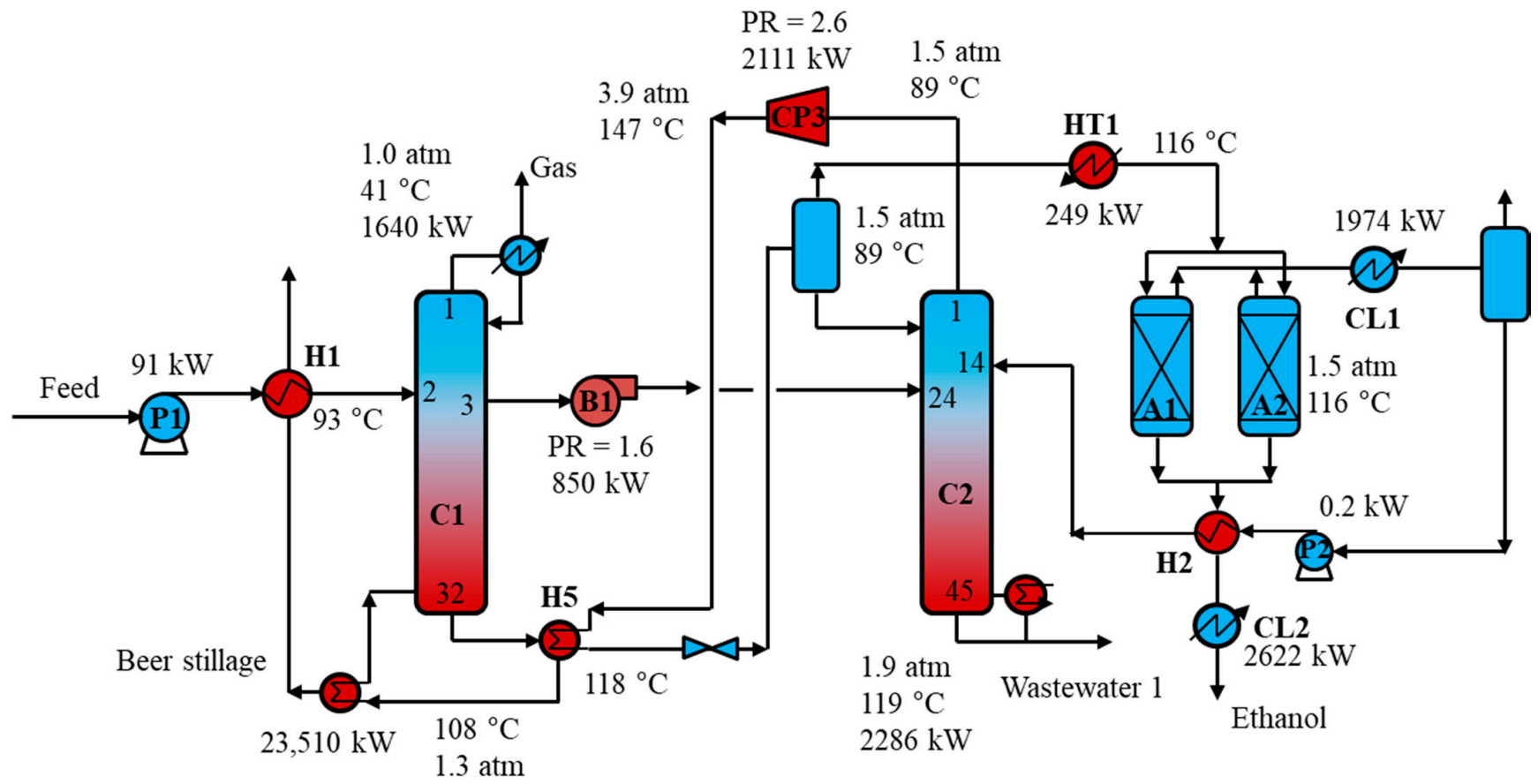

Figure 5. Schematic diagram of HI-HDA for the CE production process from lignocellulosic fermentation broth. P12: pump; H1-5: heat exchangers; CP3: compressor; CL1-2: coolers; HT1: heater; C1-2: distillation columns; A1-2: adsorption columns.

In addition, the side vapor of $\mathrm{C} 1$ was pressurized from $1.0 \mathrm{~atm}$ to $1.6 \mathrm{~atm}$ before being fed to $\mathrm{C} 2$. In this case, a blower with a pressure ratio of 1.6 was sufficient. The hot outlet of heat exchanger $\mathrm{H} 5$ was depressurized to $1.5 \mathrm{~atm}$ before being split into two streams: a liquid stream which was refluxed to $\mathrm{C} 2$ and a vapor stream which was heated to $116^{\circ} \mathrm{C}$ before being fed into the adsorption column. Table 4 lists the key results of all structural alternatives for $\mathrm{CE}$ production process including energy requirements, production costs, and total amount of $\mathrm{CO}_{2}$ emissions. The results show that the HI-HDA process can save up to $80.4 \%$ and $43.5 \%$ of energy requirements in the condensers and reboilers, respectively, compared to the conventional CE production process. Although the TIC of the HI process was $50.6 \%$ higher than that of the CE base case, the HI-HDA process can save $36.9 \%$ and $33.6 \%$ of TAC and TCE, respectively, compared to the conventional CE production process.

Table 4. Comparison of different structural alternatives for CE production process.

\begin{tabular}{|c|c|c|c|c|}
\hline Structural Alternative & $\begin{array}{c}\text { Conventional } \\
\text { Process }\end{array}$ & HP Process & MED Process & HI Process \\
\hline Reboiler duties (kW) & 46,118 & 29,268 & 28,175 & 26,045 \\
\hline Reboiler duty savings (\%) & & $36.5 \%$ & $38.9 \%$ & $43.5 \%$ \\
\hline Condenser duties $(\mathrm{kW})$ & 18,401 & 5072 & 3614 & 3614 \\
\hline Condenser duty savings (\%) & & $72.4 \%$ & $80.4 \%$ & $80.4 \%$ \\
\hline Total investment costs (US k\$) & 10,121 & 17271 & 16889 & 15246 \\
\hline Total investment cost savings (\%) & & $-70.7 \%$ & $-66.9 \%$ & $-50.6 \%$ \\
\hline Total operating costs (US k\$/year) & 18,743 & 11,823 & 11,367 & 10,511 \\
\hline Total operating cost savings (\%) & & $36.9 \%$ & $39.4 \%$ & $43.9 \%$ \\
\hline Total annual costs (US k\$/year) & 20,252 & 14,397 & 13,884 & 12,783 \\
\hline Total annual cost savings (\%) & & $28.9 \%$ & $31.4 \%$ & $36.9 \%$ \\
\hline Total carbon emissions (ton/year) & 94,071 & 74,306 & 70,348 & 62,472 \\
\hline Total carbon emission reduction (\%) & & $21.0 \%$ & $25.2 \%$ & $33.6 \%$ \\
\hline
\end{tabular}




\subsubsection{Proposed HI-HDA Process for Coproduction of CE, Heat, Electricity}

Figure 6 shows the key design parameters of the proposed HI-HDA process for coproduction of $\mathrm{CE}$, heat, and electricity from fermentation broth. The HI-HDA configuration was proposed for improving the $\mathrm{CE}$ process while the turbogenerator was redesigned to match the steam demand of the CE process. In particular, the superheated steam was used to drive the turbine $\mathrm{T} 1$ to become the LP steam $\left(9.5 \mathrm{~atm}, 236^{\circ} \mathrm{C}\right)$ before being split into three steams. $19 \mathrm{wt} \%$ of the LP steam was used for the C1, C2 reboilers and heater HT1. $70 \mathrm{wt} \%$ of the LP steam was used to drive the turbine $\mathrm{T} 2$ to produce electricity with the isentropic efficiency of $85 \%$. The T2 outlet at $0.1 \mathrm{~atm}$ and $46{ }^{\circ} \mathrm{C}$ was then condensed and pumped back to the boiler. The rest of the steam $(11 \mathrm{wt} \%)$ was used to preheat the boiler feed water before it was fed to the boiler. The results showed that the CHP process could supply sufficient heat and power demand for the CE production process. In addition, 45.85 MW electricity was generated for selling back to the grid. The proposed HI-HDA coproduction process can increase $12.0 \%$ of electricity with respect to the conventional coproduction process. Note that the $\mathrm{CE}$ recovery process was thermal neutral in both conventional and proposed coproduction processes.

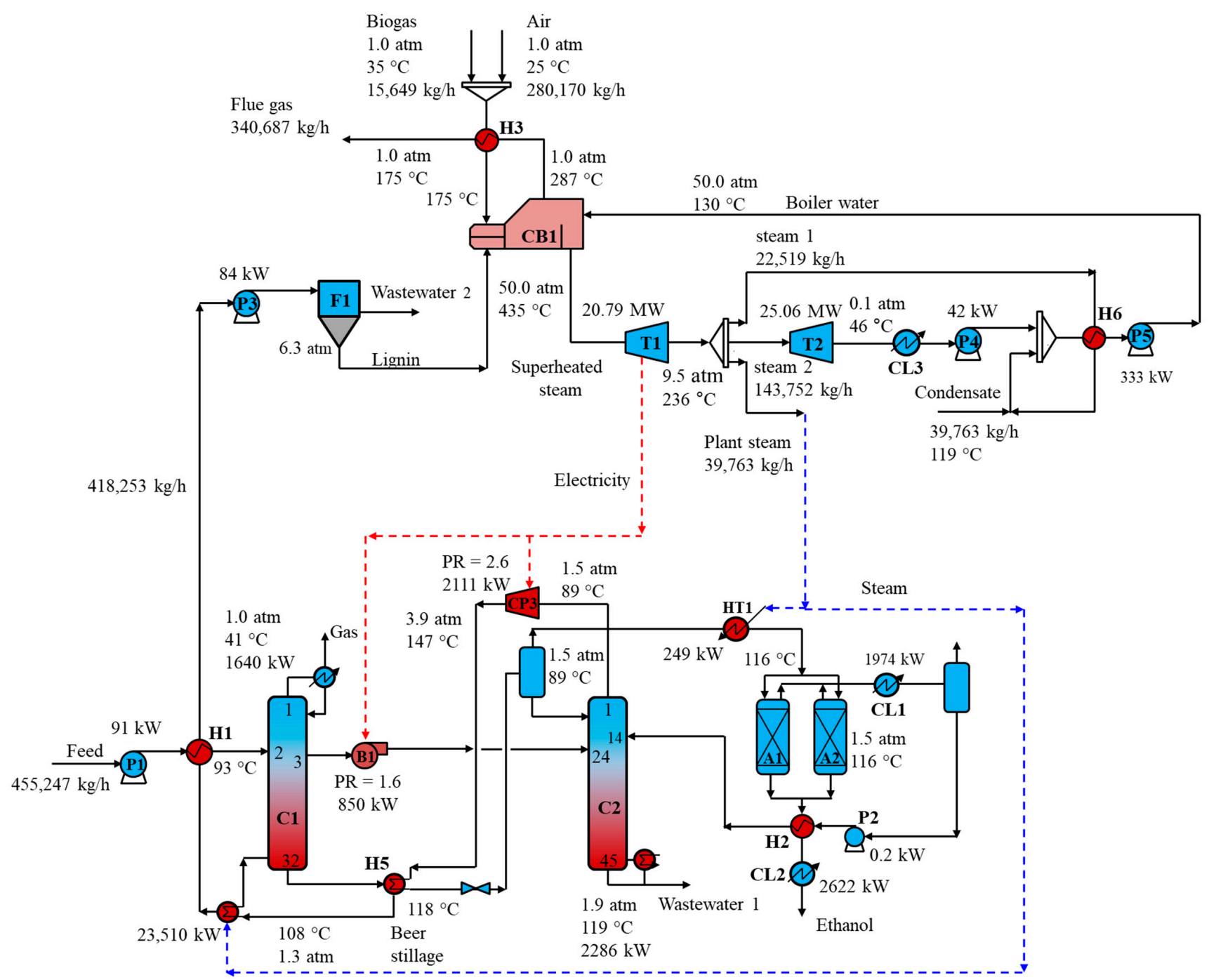

Figure 6. Schematic diagram of proposed HI-HDA process for coproduction of $\mathrm{CE}$, heat, and electricity from lignocellulosic fermentation broth. P1-5: Pumps; H1-5: heat exchangers; C1-2: distillation columns; A1-2: adsorption columns; HT1: heater; CL1-3: coolers; T1-2: turbines; CB1: combustor + boiler; F1: pressure filter; CP3: compressor; B1: blower. 
From the actual fermentation broth, a cost-efficient design for the coproduction of $\mathrm{CE}$, heat, and electricity were developed in this study. It was found that utilizing the lignin fraction of lignocellulosic biomass means attaining a higher certain degree of integration in a biorefinery context.

\section{Conclusions}

In this study, a cost-efficient and sustainable design was proposed for coproduction of $\mathrm{CE}$, heat, and electricity from the actual lignocellulosic fermentation broth. The conventional coproduction process was successfully designed and optimized to achieve the targets. Various HI techniques such as HP, MED, and combined HP-MED demonstrated as attractive solutions to improve the conventional $\mathrm{CE}$ process. In particular, the results show that the proposed HI-HDA process can save $36.9 \%$ and $33.6 \%$ of $\mathrm{TAC}$ and $\mathrm{CO}_{2}$ emission, respectively, compared to the $\mathrm{CE}$ conventional process. The biomass $\mathrm{CHP}$ process were efficiently integrated with the CE production process. The CHP process, which utilized the lignin and unconverted cellulose and hemicellulose, supplied sufficient steam and power for the $\mathrm{CE}$ recovery process to make the $\mathrm{CE}$ plant become thermal neutral. The proposed HI-HDA coproduction process can generate $12.0 \%$ more electricity than the conventional coproduction process. Furthermore, the solid waste disposal costs were reduced substantially and additional profit was generated from selling excess electricity back to the grid. The proposed coproduction process can be proposed both for constructing a new CE plant and a retrofit project which requires a short modification time. The results of this study provide a strong basis for the design and improvement of more sustainable CE production technologies from lignocellulosic biomass.

Author Contributions: L.C.N. and N.V.D.L. contributed equally to this work by designing the study, by performing the process simulations, and by writing the article. M.L. conceived the core research concepts and advised academically. All authors have read and agreed to the published version of the manuscript.

Funding: This work was supported by the Priority Research Centers Program through the National Research Foundation (NRF) of Korea funded by the Ministry of Education (2014R1A6A1031189).

Institutional Review Board Statement: Not applicable.

Informed Consent Statement: Not applicable.

Conflicts of Interest: The authors declare no conflict of interest.

$\begin{array}{ll}\text { Abbreviations } \\ \text { AD } & \begin{array}{l}\text { azeotropic distillation } \\ \text { cellulosic ethanol }\end{array} \\ \mathrm{CE} & \text { combined heat and power } \\ \mathrm{CHP} & \text { chemical oxygen demand } \\ \mathrm{COD} & \text { carbon dioxide } \\ \mathrm{CO} 2 & \text { extractive distillation } \\ \mathrm{ED} & \text { ethylene glycol } \\ \mathrm{EG} & \text { hybrid distillation adsorption } \\ \mathrm{HDA} & \text { heat integrated } \\ \mathrm{HI} & \text { heat pump } \\ \mathrm{HP} & \text { low pressure } \\ \text { LP } & \text { multiple-effect distillation } \\ \text { MED } & \text { million gallons per year } \\ \text { MMgy } & \text { mechanical vapor recompression } \\ \text { MVR } & \text { net heating value } \\ \text { NHV } & \text { National Renewable Energy Laboratory } \\ \text { NREL } & \end{array}$




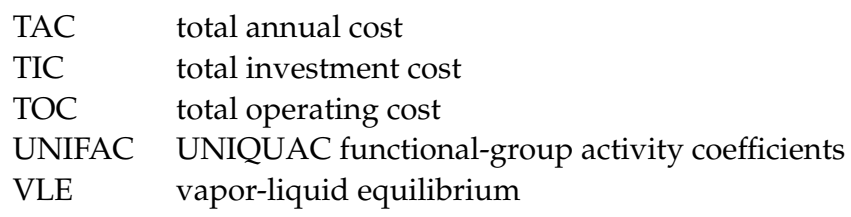

\section{Appendix A Chemical Oxygen Demand (COD)}

Equation of the oxidation of an arbitrary organic compound [16]:

$$
\mathrm{C}_{n} \mathrm{H}_{a} \mathrm{O}_{b} \mathrm{~N}_{c}+\left(n+\frac{a}{4}-\frac{b}{2}-\frac{3}{4} c\right) \mathrm{H}_{2} \mathrm{O}+c \mathrm{NH}_{3}
$$

Equation of mass COD [16]:

$$
\operatorname{COD}_{m}=\left(n+\frac{a}{4}-\frac{b}{2}-\frac{3}{4} c\right) \frac{M_{w}\left(\mathrm{O}_{2}\right)}{M_{w}\left(C_{n} H_{a} O_{b} N_{c}\right)}
$$

Table A1. Calculated mass COD for compounds in the wastewater.

\begin{tabular}{cc}
\hline Compound & COD $_{\mathrm{m}}$ \\
\hline Lactic acid & 1.065 \\
Levulinic acid & 1.516 \\
Furfural & 1.665 \\
Acetic acid & 1.067 \\
Formic acid & 0.348 \\
Extractives & 1.065 \\
Glucose & 1.065 \\
Xylose & 1.067 \\
\hline
\end{tabular}

\section{References}

1. Nitsos, C.K.; Matis, K.A.; Triantafyllidis, K.S. Optimization of Hydrothermal Pretreatment of Lignocellulosic Biomass in the Bioethanol Production Process. ChemSusChem 2013, 6, 110-122. [CrossRef] [PubMed]

2. Claassen, P.A.M.; van Lier, J.B.; Lopez Contreras, A.M.; van Niel, E.W.J.; Sijtsma, L.; Stams, A.J.M.; de Vries, S.S.; Weusthuis, R.A. Utilisation of biomass for the supply of energy carriers. Appl. Microbiol. Biotechnol. 1999, 52, 741-755. [CrossRef]

3. Christian, S. Is Cellulosic Ethanol the Next Big Thing in Renewable Fuels? Earth Island Journal. 5 January 2015. Available online: https://www.earthisland.org/journal/index.php/articles/entry/is_cellulosic_ethanol_the_next_big_thing_in_renewable_ fuels / (accessed on 28 April 2021).

4. Halder, P.; Azad, K.; Shah, S.; Sarker, E. Prospects and technological advancement of cellulosic bioethanol ecofuel production. In Advances in Eco-Fuels for a Sustainable Environment; Elsevier: Amsterdam, The Netherlands, 2019; pp. 211-236.

5. Dale, B.E.; Anderson, J.E.; Brown, R.C.; Csonka, S.; Dale, V.H.; Herwick, G.; Jackson, R.D.; Jordan, N.; Kaffka, S.; Kline, K.L.; et al. Take a Closer Look: Biofuels Can Support Environmental, Economic and Social Goals. Environ. Sci. Technol. 2014, 48, 7200-7203. [CrossRef]

6. Balan, V.; Chiaramonti, D.; Kumar, S. Review of US and EU initiatives toward development, demonstration, and commercialization of lignocellulosic biofuels. Biofuels Bioprod. Biorefin. 2013, 7, 732-759. [CrossRef]

7. Rosales-Calderon, O.; Arantes, V. A review on commercial-scale high-value products that can be produced alongside cellulosic ethanol. Biotechnol. Biofuels 2019, 12, 240. [CrossRef] [PubMed]

8. Scott, A. Clariant bets big on cellulosic ethanol. Chem. Eng. News 2018, 96, 7.

9. Huang, H.-J.; Ramaswamy, S.; Tschirner, U.W.; Ramarao, B. V A review of separation technologies in current and future biorefineries. Sep. Purif. Technol. 2008, 62, 1-21. [CrossRef]

10. Humbird, D.; Davis, R.; Tao, L.; Kinchin, C.; Hsu, D.; Aden, A.; Schoen, P.; Lukas, J.; Olthof, B.; Worley, M.; et al. Process Design and Economics for Biochemical Conversion of Lignocellulosic Biomass to Ethanol: Dilute-Acid Pretreatment and Enzymatic Hydrolysis of Corn Stover; National Renewable Energy Laboratory: Golden, CO, USA, 2011.

11. Kiss, A.A.; Suszwalak, D.J.P.C. Enhanced bioethanol dehydration by extractive and azeotropic distillation in dividing-wall columns. Sep. Purif. Technol. 2012, 86, 70-78. [CrossRef]

12. Loy, Y.Y.; Lee, X.L.; Rangaiah, G.P. Bioethanol recovery and purification using extractive dividing-wall column and pressure swing adsorption: An economic comparison after heat integration and optimization. Sep. Purif. Technol. 2015, 149, 413-427. [CrossRef] 
13. Frolkova, A.K.; Raeva, V.M. Bioethanol dehydration: State of the art. Theor. Found. Chem. Eng. 2010, 44, 545-556. [CrossRef]

14. Kiss, A.A.; Ignat, R.M. Innovative single step bioethanol dehydration in an extractive dividing-wall column. Sep. Purif. Technol. 2012, 98, 290-297. [CrossRef]

15. Schladt, L.; Ivens, I.; Karbe, E.; Ruhl-Fehlert, C.; Bomhard, E. Subacute oral toxicity of tetraethylene-glycol and ethylene-glycol administered to Wistar rats. Exp. Toxicol. Pathol. 1998, 50, 257-265. [CrossRef]

16. Strømsnes, L.M. Process Modeling of a Biorefinery for Integrated Production of Ethanol and Furfural in HYSYS. Master's Thesis, Norwegian University of Science and Technology, Trondheim, Norway, 2016.

17. Torres-Ortega, C.E.; Rong, B.-G. Synthesis and Simulation of Efficient Divided Wall Column Sequences for Bioethanol Recovery and Purification from an Actual Lignocellulosic Fermentation Broth. Ind. Eng. Chem. Res. 2016, 55, 7411-7430. [CrossRef]

18. Grisales Díaz, V.H.; Willis, M.J.; von Stosch, M.; Olivar Tost, G.; Prado-Rubio, O. Assessing the energy requirements for butanol production using fermentation tanks-in-series operated under vacuum. Renew. Energy 2020, 160, 1253-1264. [CrossRef]

19. Pröll, T.; Zerobin, F. Biomass-based negative emission technology options with combined heat and power generation. Mitig. Adapt. Strateg. Glob. Chang. 2019, 24, 1307-1324. [CrossRef]

20. Rashid, T.; Ali Ammar Taqvi, S.; Sher, F.; Rubab, S.; Thanabalan, M.; Bilal, M.; ul Islam, B. Enhanced lignin extraction and optimisation from oil palm biomass using neural network modelling. Fuel 2021, 293, 120485. [CrossRef]

21. Rasheed, T.; Anwar, M.T.; Ahmad, N.; Sher, F.; Khan, S.U.-D.; Ahmad, A.; Khan, R.; Wazeer, I. Valorisation and emerging perspective of biomass based waste-to-energy technologies and their socio-environmental impact: A review. J. Environ. Manag. 2021, 287, 112257. [CrossRef]

22. Nhien, L.C.; Long, N.V.D.; Lee, M. Novel Hybrid Reactive Distillation with Extraction and Distillation Processes for Furfural Production from an Actual Xylose Solution. Energies 2021, 14, 1152. [CrossRef]

23. Nhien, L.C.; Long, N.V.D.; Kim, S.; Lee, M. Design and optimization of intensified biorefinery process for furfural production through a systematic procedure. Biochem. Eng. J. 2016, 116, 166-175. [CrossRef]

24. Biegler, L.T.; Grossmann, I.E.; Westerberg, A.W. Systematic Methods of Chemical Process Design; Prentice Hall: Hoboken, NJ, USA, 1997.

25. Turton, R.; Bailie, R.C.; Whiting, W.B.; Shaeiwitz, J.A.; Bhattacharyya, D. Analysis, Synthesis, and Design of Chemical Processes, 4th ed.; Prentice Hall: Hoboken, NJ, USA, 2016.

26. Gadalla, M.A.; Olujic, Z.; Jansens, P.J.; Jobson, M.; Smith, R. Reducing $\mathrm{CO}_{2}$ emissions and energy consumption of heat-integrated distillation systems. Environ. Sci. Technol. 2005, 39, 6860-6870. [CrossRef]

27. Kiss, A.A.; Flores Landaeta, S.J.; Infante Ferreira, C.A. Towards energy efficient distillation technologies-Making the right choice. Energy 2012, 47, 531-542. [CrossRef]

28. Nhien, L.C.; Long, N.V.D.; Lee, M. Novel heat-integrated and intensified biorefinery process for cellulosic ethanol production from lignocellulosic biomass. Energy Convers. Manag. 2017, 141, 367-377. [CrossRef]

29. Tomczyk, J. The Professor: Compressor Overheating. The ACHR NEWS. 5 April 2010. Available online: https://www.achrnews. com/articles/114251-the-professor-compressor-overheating (accessed on 28 April 2021). 